\title{
Vitamin $C$ enhances anticancer activity in methotrexate-treated Hep3B hepatocellular carcinoma cells
}

\author{
GIOU-TENG YIANG ${ }^{1,2^{*}}$, PEI-LUN CHOU ${ }^{3,4^{*}}$, YU-TING HUNG ${ }^{5}$, JEN-NI CHEN $^{6}$, \\ WEI-JUNG $\mathrm{CHANG}^{7}$, YUNG-LUEN YU ${ }^{7,8}$ and CHYOU-WEI WEI ${ }^{5}$
}

\begin{abstract}
${ }^{1}$ Department of Emergency Medicine, Taipei Tzu Chi Hospital, Buddhist Tzu Chi Medical Foundation, New Taipei 231; ${ }^{2}$ Department of Emergency Medicine, School of Medicine, Tzu Chi University, Hualien 970; ${ }^{3}$ Division of Allergy-Immunology-Rheumatology, Department of Internal Medicine, Saint Mary's Hospital Luodong, Yilan 265; ${ }^{4}$ Department of Internal Medicine, School of Medicine, College of Medicine, Taipei Medical University, Taipei 110; ${ }^{5}$ Department of Nutrition, Master Program of Biomedical Nutrition, Hungkuang University, Shalu, Taichung 433; ${ }^{6}$ Department of Food Science and Biotechnology, National Chung Hsing University, Taichung 402;

${ }^{7}$ Graduate Institute of Cancer Biology, and Center for Molecular Medicine, China Medical University, Taichung $404 ;{ }^{8}$ Department of Biotechnology, Asia University, Taichung 413, Taiwan, R.O.C.
\end{abstract}

Received March 6, 2014; Accepted April 25, 2014

DOI: $10.3892 / o r .2014 .3289$

\begin{abstract}
Methotrexate (MTX) has been widely used for rheumatoid arthritis therapy for a long time. MTX is also used as an anticancer drug for various tumors. However, many studies have shown that high-dose MTX treatment for cancer therapy may cause liver and renal damage. Alhough the mechanisms involved in MTX-induced liver and renal damage require further research, many studies have indicated that MTX-induced cytotoxicity is associated with increases in oxidative stress and caspase activation. In order to reduce MTX-induced side-effects and increase anticancer efficiency, currently, combination treatments of low-dose MTX and other anticancer drugs are considered and applied for various tumor treatments. The present study showed that MTX induces increases in $\mathrm{H}_{2} \mathrm{O}_{2}$ levels and caspase-9/-3 activation leading to cell death in hepatocellular carcinoma Hep3B cells. Importantly, this study is the first to demonstrate that vitamin $\mathrm{C}$ can efficiently aid low-dose MTX in inducing cell death in Hep3B cells. Therefore, the present study provides
\end{abstract}

Correspondence to: Dr Yung-Luen Yu, Graduate Institute of Cancer Biology and Center for Molecular Medicine, China Medical University, Taichung 404, Taiwan, R.O.C.

E-mail: ylyu@mail.cmu.edu.tw

Dr Chyou-Wei Wei, Department of Nutrition, Master Program of Biomedical Nutrition, Hungkuang University, Shalu, Taichung 433, Taiwan, R.O.C.

E-mail: chyouweiwei@gmail.com

*Contributed equally

Key words: methotrexate, vitamin C, apoptosis, hepatocellular carcinoma a possible powerful therapeutic method for tumors using a combined treatment of vitamin C and low-dose MTX.

\section{Introduction}

Methotrexate (MTX) is one of the most popular and safe antirheumatic drugs under the applied treatment dose $(1,2)$. In order to obtain a better curative effect in clinical cases, MTX is also used in combination with other drugs for rheumatoid arthritis treatment $(1,3,4)$. In addition, MTX is also used as an anticancer drug (5). Recently, MTX has been widely applied for the treatment of various cancers, such as hepatoma, osteosarcoma, leukemia, lymphoma, gastric, breast, head and neck cancers (5-9). Many studies have demonstrated that MTX induces cancer cell death via apoptotic death pathways (10-14). Apoptotic death pathways can be divided into caspase-dependent and caspase-independent cascades $(15,16)$. Concerning the MTX-induced apoptotic pathways, most studies have shown that MTX induces apoptosis via caspase-dependent cascades in many cancer cell lines (17-21). However, some studies have indicated that MTX can induce apoptosis via caspase-independent cascades in osteosarcoma cells $(22,23)$. The present study found that MTX-induced apoptosis in Hep3B cells is via the caspase-dependent cascade, similar to most other studies (17-21).

Two major caspase cascade pathways have been reported (24-26). One is the caspase-8/-3 cascade, known as the extrinsic death receptor pathway (CD95/APO-1/Fas receptor) (27-29). Another is the caspase-9/-3 cascade, known as the intrinsic mitochondrial death pathway $(27,30,31)$. Some studies have shown that MTX-induced apoptosis is mediated by the caspase-9/-3 cascade pathway in choriocarcinoma, breast cancer, oral squamous carcinoma and hepatoma cells $(18,19,21,32,33)$. In contrast, some studies demonstrated that MTX-induced apoptosis is mediated through the caspase-8/-3 cascade pathway in breast cancer, hepatoma and leukemia 
cells $(17,33,34)$. The present study showed that MTX activates the caspase-9/-3 cascade in Hep3B cells, but not the caspase8/-3 cascade.

Previously, many studies have shown that high-dose MTX treatment can induce increased oxidative stress, resulting in renal and liver damage (3,35-37). However, the specific reactive oxygen species (ROS) induced by MTX treatment have not been identified. $\mathrm{O}_{2}^{-}$and $\mathrm{H}_{2} \mathrm{O}_{2}$ are ROS families generally existing in many cells. By using the lucigenin-amplified method (38-40), our results are the first to demonstrate that MTX can induce increases in $\mathrm{H}_{2} \mathrm{O}_{2}$ levels, but not $\mathrm{O}_{2}^{-}$levels.

Considering that high-dose MTX treatments can cause renal and liver damage (35-37), combination treatments of low-dose MTX and other anticancer drugs are suggested and applied during clinical cancer therapy in order to enhance the anticancer effects and decrease MTX-induced sideeffects $(9,10,12,18,41)$. However, not all anticancer agents can enhance the anticancer effects of low-dose MTX. A recent study showed that aspirin can antagonize the MTX-induced cytotoxic effect on lung cancer cells (42). Alternatively, there have been many reports on the antioxidant activities of vitamin C (43-47). Moreover, some studies have demonstrated that vitamin $\mathrm{C}$ can exert anticancer activities in various cancer cells (48-52). The present study demonstrated that vitamin $\mathrm{C}$ can diminish MTX-induced increases in $\mathrm{H}_{2} \mathrm{O}_{2}$ levels. On the other hand, it is worth noting that vitamin $\mathrm{C}$ can help low-dose MTX exert a cytotoxic effect on Hep3B cells. Taken together, the study demonstrated that MTX activates the caspase-9/-3 cascade and induces increased $\mathrm{H}_{2} \mathrm{O}_{2}$ levels, causing cell cytotoxicity in Hep3B cells, while more importantly, the present study is the first to demonstrate that vitamin $\mathrm{C}$ enhances the anticancer efficiency in MTX-treated Hep3 cells.

\section{Materials and methods}

Chemicals and materials. Methotrexate was purchased from Pfizer Inc. MTT assay kit was purchased from Bio Basic Canada Inc. Hoechst 33342, vitamin C, lucigenin and luminol were purchased from Sigma. Caspase-3 like substrate (Ac-DEVD-pNA), caspase-8 substrate (Ac-IETD-pNA) and caspase-9 substrate (Ac-LEHD-pNA) were purchased from AnaSpec, Inc. (San Jose, CA, USA). Fetal bovine serum (FBS), Dulbecco's modified Eagle's medium (DMEM), non-essential amino acid, L-glutamine and penicillin/streptomycin were purchased from Gibco-BRL.

Cell cultures. Hep3B cells were cultured in DMEM containing 10\% FBS, 2 mM L-glutamine, $100 \mathrm{IU} / \mathrm{ml}$ penicillin/streptomycin, and $0.1 \mathrm{mM}$ non-essential amino acids. The cells were cultured at $37^{\circ} \mathrm{C}$ in a humidified atmosphere containing $5 \%$ $\mathrm{CO}_{2}$.

Cell viability assay. Hep3B cell viability was assessed using the MTT assay method according to the manufacturer's instructions. In brief, Hep3B cells were maintained in each well of 96-well culture plates. Every $24 \mathrm{~h}$, the control group and experimental groups were subjected to the MTT assay kit. After $3 \mathrm{~h}$ of incubation, absorbance at $570 \mathrm{~nm}$ for each well containing Hep3B cells was detected under a multiwell ELISA reader (Molecular Devices). Cell viability was calculated using the following formula: A570 experimental group/A570 control group x $100 \%$.

Nuclear condensation and DNA fragmentation. Apoptotic cells were identified by nuclear condensation and DNA fragmentation using Hoechst 33342 staining. Cells were treated with $10 \mu \mathrm{g} / \mathrm{ml}$ Hoechst 33342 for $10 \mathrm{~min}$. Nuclear condensation and DNA fragmentation were observed under a fluorescence microscope (excitation, $352 \mathrm{~nm}$; emission, $450 \mathrm{~nm})(53,54)$.

Caspase activity assay. Caspase activity assays were executed according to previous studies $(55,56)$. In brief, Hep3B cells were lysed with a lysis buffer $(50 \mathrm{mM}$ Tris- $\mathrm{HCl}, 120 \mathrm{mM} \mathrm{NaCl}$, $1 \mathrm{mM}$ EDTA, 1\% NP-40, $\mathrm{pH} 7.5)$ and protease inhibitors. After centrifugation $\left(15,000 \mathrm{x} \mathrm{g}, 30 \mathrm{~min}, 4^{\circ} \mathrm{C}\right)$ cell pellets were collected. The working solutions containing $40 \mu \mathrm{l}$ cell lysates (80 $\mu \mathrm{g}$ total protein), $158 \mu \mathrm{l}$ reaction buffer (20\% glycerol, $0.5 \mathrm{mM}$ EDTA, $5 \mathrm{mM}$ dithiothreitol, $100 \mathrm{mM}$ HEPES, $\mathrm{pH}$ 7.5) and $2 \mu \mathrm{l}$ fluorogenic caspase substrate (Ac-LEHD-pNA, Ac-DEVD-pNA or Ac-IETD-pNA) were incubated at $37^{\circ} \mathrm{C}$ for $6 \mathrm{~h}$. Fluorogenic substrate cleavage was determined at $405 \mathrm{~nm}$ in an ultra-microplate reader (BioTek Instruments). The fold increase in caspase activity was calculated using the following formula: (A405 experimental group - A405 control group)/ A405 control group.

Determination of $\mathrm{H}_{2} \mathrm{O}_{2}$ and $\mathrm{O}_{2}^{-}$levels. $\mathrm{H}_{2} \mathrm{O}_{2}$ and $\mathrm{O}_{2}^{-}$levels were examined by using lucigenin-amplified chemiluminescence according to the lucigenin-amplified method $(57,58)$. In brief, for $\mathrm{H}_{2} \mathrm{O}_{2}$ levels, the sample $(200 \mu \mathrm{l})$ was mixed with $0.2 \mathrm{mmol} / \mathrm{l}$ luminol solution $(100 \mu \mathrm{l})$. After that, the mixture was measured with a chemiluminescence analyzing system (CLA-FSI; Tohoko Electronic Industrial Co., Ltd., Miyagi, Japan) for determination. For $\mathrm{O}_{2}^{-}$levels, $200 \mu \mathrm{l}$ of the sample was mixed with $0.1 \mathrm{mmol} / \mathrm{l}$ of lucigenin solution $(500 \mu \mathrm{l})$, and was then measured by the CLA-FSI chemiluminescence analyzing system.

Statistical analysis. Experimental data were calculated from three independent triplicate experiments and are presented as the mean values of the chosen triplicate groups. These experimental data are shown as means with standard deviations.

\section{Results}

MTX exerts dose-dependent and time-dependent anticancer effects on Hep3B cells. In clinical cases, 10-25 mg/week MTX $(\sim 0.1 \mu \mathrm{M} /$ day) is a safely applied dose for rheumatoid arthritis treatment $(1,2,59)$. In the present study, $0.1 \mu \mathrm{M}$ (treatmentdose), $0.01 \mu \mathrm{M}$ (low-dose) and $10 \mu \mathrm{M}$ (high-dose) MTX were used for studying the anticancer effects on Hep3B cells. Hep3B cell viability decreased in the 0.1 and $10 \mu \mathrm{M}$ MTX treatment groups, but did not decrease in the $0.01 \mu \mathrm{M}$ treatment group (Fig. 1). In addition, the $10 \mu \mathrm{M}$ MTX treatment group showed a stronger cytotoxic effect in the Hep3B cells than the $0.1 \mu \mathrm{M}$ MTX treatment group. These data suggest that MTX exerts a dose-dependent anticancer effect on Hep3B cells. In addition, cell viability was observed over different MTX incubation times, with results showing that the cell viability decreased incrementally in the 0.1 and $10 \mu \mathrm{M}$ MTX groups. The present 


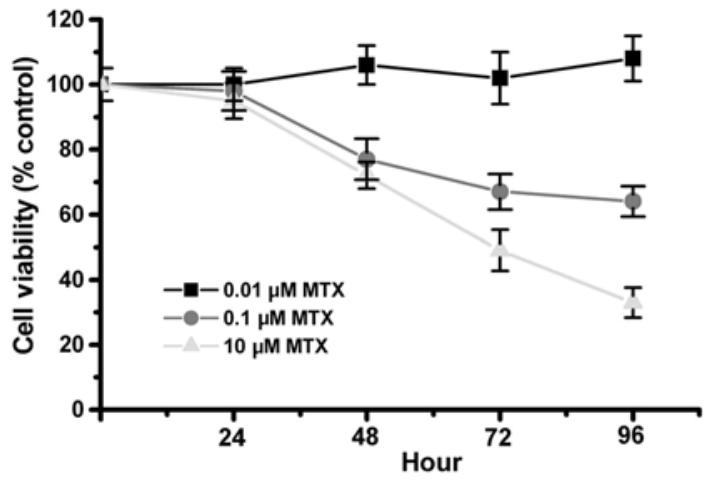

Figure 1. Cell viability. Hep3B cells were treated with $10,0.1$ and $0.01 \mu \mathrm{M}$ MTX. Cell viability was measured with MTT assay every $24 \mathrm{~h}$ and presented as A570 experimental group/A570 control group x 100\%. Data were collected from 4 independent experiments and are presented as mean $\pm \mathrm{SD}$.
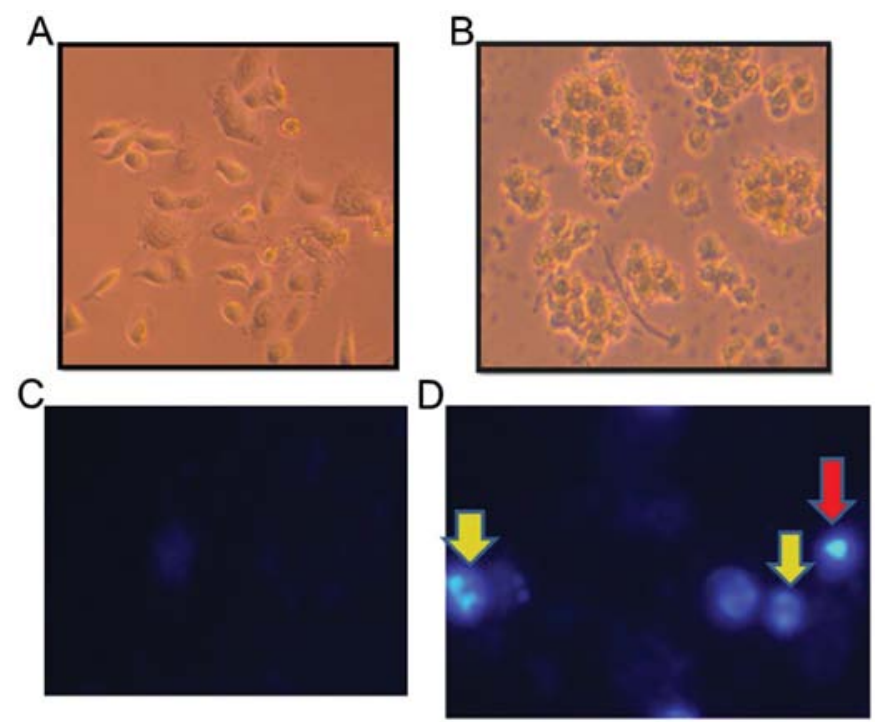

Figure 2. Cell morphology, nuclear condensation and DNA fragmentation. (A) Control cells, (B) MTX-treated cells. Hep3B cells were treated with or without $10 \mu \mathrm{M}$ MTX for $96 \mathrm{~h}$, and cell morphology was observed under a phase-contrast microscope. (C) Control cells, (D) MTX-treated cells. Cells were treated with or without $10 \mu \mathrm{M}$ MTX for $96 \mathrm{~h}$, and nuclear condensation and DNA fragmentation were observed using Hoechst 33342 staining. Note that nuclear condensation (red arrow) and DNA fragmentation (yellow arrow) were noted in the MTX-treated cells.

study indicates that MTX exerts a dose-dependent and timedependent anticancer effect on Hep3B cells.

MTX induces apoptosis and activates the caspase-9/-3 cascade in Hep3B cells. The study investigated whether MTX induces apoptosis in Hep3B cells. Cell morphology was observed under a phase-contrast microscope. Hep3B cells survived with morphology intact in the control group (Fig. 2A). However, dead cells were noted in the MTX treatment group (Fig. 2B). In addition, nuclear condensation and DNA fragmentation are apoptotic features and can be observed using a nuclear staining method, as previously described $(55,60)$. Compared with the control group (Fig. 2C), nuclear condensation and DNA fragmentation were noted in the MTX-treated group (Fig. 2D). The results indicate that MTX induced apoptosis in the Hep3B cells. Next, caspase activation was determined in the
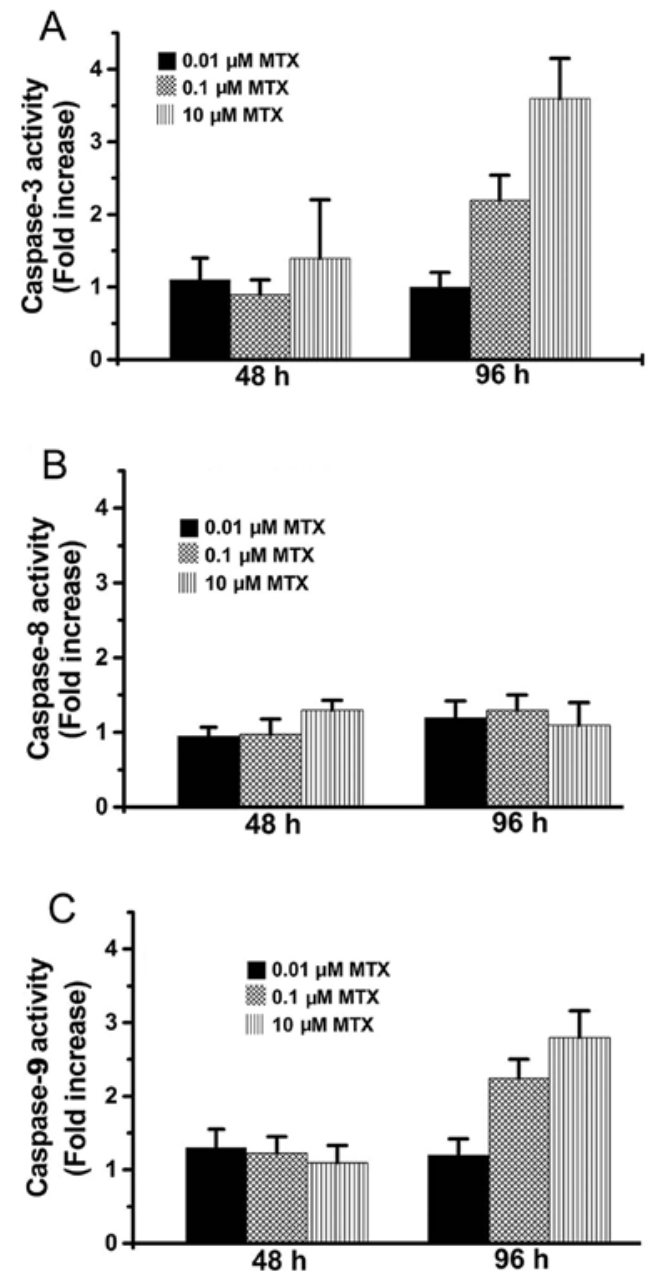

Figure 3. Caspase activity. (A) Caspase-3, (B) caspase-8 and (C) caspase-9 activities were determined at 48 and $96 \mathrm{~h}$ in Hep3B cells treated with $0.01 \mu \mathrm{M}$, $0.1 \mu \mathrm{M}$ and $10 \mu \mathrm{M}$ MTX . Note that caspase- 3 and caspase- 9 activities were significantly increased in the 0.1 and $10 \mu \mathrm{M}$ MTX-treated cells. Data were obtained from 3 independent experiments and are presented as means \pm SD.

MTX-treated Hep3B cells by using a substrate cleavage assay $(56,61)$. As shown in Fig. 3A, caspase-3 activity increased in the Hep3B cells at $96 \mathrm{~h}$ following treatment with 0.1 and $10 \mu \mathrm{M}$ MTX while caspase-3 activity did not increase in Hep3B cells following treatment with $0.01 \mu \mathrm{M}$ MTX. Caspase- 9 activity also increased in the 0.1 and $10 \mu \mathrm{M}$ MTX-treated Hep3B cells at $96 \mathrm{~h}$ but did not increase in the $0.01 \mu \mathrm{M}$ MTX-treated cells (Fig. 3C). However, there was no obvious increase in caspase-8 activity among the MTX-treated Hep3B cells (Fig. 3B). These results suggest that MTX $(10$ and $0.1 \mu \mathrm{M})$ induced apoptosis in the Hep3B cells via the caspase-9/-3 cascade but not via the caspase- $8 /-3$ cascade.

MTX causes increases in $\mathrm{H}_{2} \mathrm{O}_{2}$ levels but not $\mathrm{O}_{2}^{-}$levels in Hep3B cells. Previous studies have shown that MTX can cause cell cytotoxicity associated with increases in reactive oxygen species (ROS) (35-37). Prior to the present study, the literature has not yet identified which ROS is induced by MTX treatment. Both $\mathrm{O}_{2}{ }^{-}$and $\mathrm{H}_{2} \mathrm{O}_{2}$ belonging to ROS commonly exist in cells. Therefore, $\mathrm{O}_{2}^{-}$and $\mathrm{H}_{2} \mathrm{O}_{2}$ levels were examined according to the lucigenin-amplified method $(57,58)$. The present study found that MTX did not raise $\mathrm{O}_{2}^{-}$levels in the Hep3B cells 

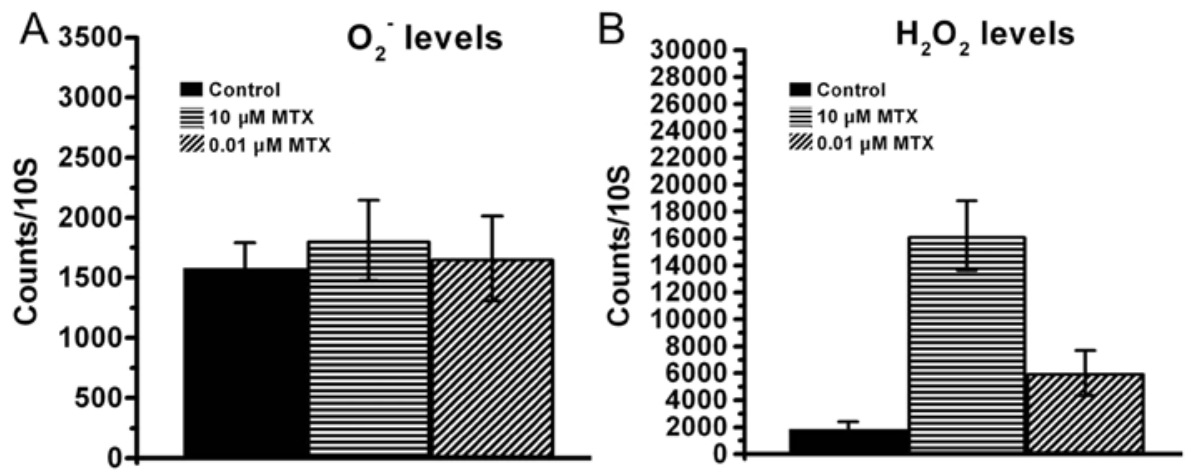

Figure 4. $\mathrm{O}_{2}{ }^{-}$and $\mathrm{H}_{2} \mathrm{O}_{2}$ levels. (A) $\mathrm{O}_{2}{ }^{-}$counts and (B) $\mathrm{H}_{2} \mathrm{O}_{2}$ counts are presented in the control cells, $0.01 \mu \mathrm{M}$ MTX-treated cells, and $10 \mu \mathrm{M}$ MTX-treated cells. $\mathrm{O}_{2}^{-}$and $\mathrm{H}_{2} \mathrm{O}_{2}$ levels were determined after treatment for $1 \mathrm{~h}$ using a lucigenin-amplified method. Data were collected from 4 independent experiments and are presented as the means $\pm \mathrm{SD}$.

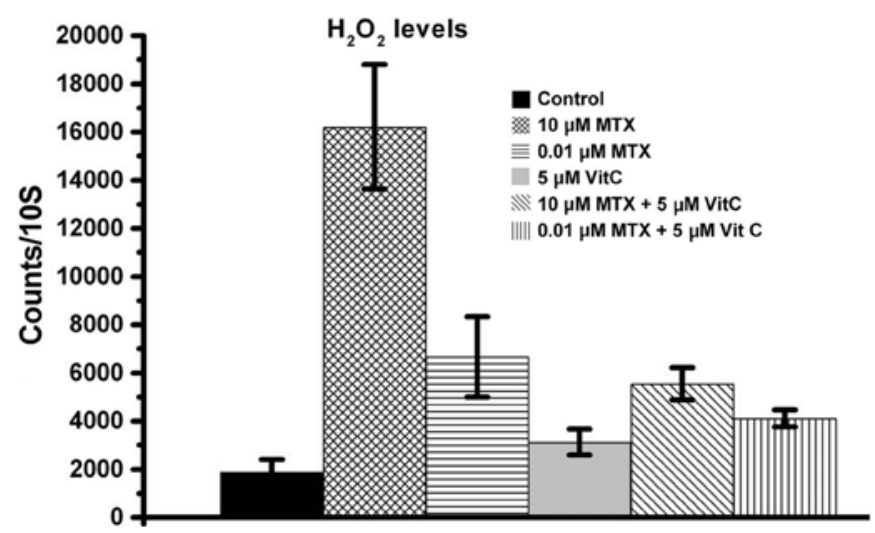

Figure 5. $\mathrm{H}_{2} \mathrm{O}_{2}$ levels. $\mathrm{H}_{2} \mathrm{O}_{2}$ counts are presented in control cells, MTXtreated cells, vitamin C-treated cells, and MTX plus vitamin C-treated cells. $\mathrm{H}_{2} \mathrm{O}_{2}$ levels were determined after treatment for $1 \mathrm{~h}$ using a lucigeninamplified method. Data were collected from 4 independent experiments and are presented as means $\pm \mathrm{SD}$.

(Fig. 4A). However, both high-dose MTX and low-dose MTX raised $\mathrm{H}_{2} \mathrm{O}_{2}$ levels in the Hep3B cells (Fig. 4B). Therefore, the MTX-induced ROS increase is related to $\mathrm{H}_{2} \mathrm{O}_{2}$ levels but not related to $\mathrm{O}_{2}^{-}$levels in the Hep3B cells.

Vitamin $\mathrm{C}$ reduces the increase in $\mathrm{H}_{2} \mathrm{O}_{2}$ levels and enhances the anticancer efficacy in MTX-treated Hep $3 B$ cells. Many studies have demonstrated that vitamin $\mathrm{C}$ can prevent oxidative stress-induced cell damage (43-47). Considering that MTX induces oxidative stress resulting in cell damage (35-37), this study examined whether vitamin $\mathrm{C}$ could decrease $\mathrm{H}_{2} \mathrm{O}_{2}$ levels, essentially inhibiting MTX-induced cytotoxicity in Hep3B cells. As shown in Fig. 5, the group receiving a combination treatment of vitamin $\mathrm{C}$ and $10 \mu \mathrm{M}$ MTX had lower $\mathrm{H}_{2} \mathrm{O}_{2}$ levels than the $10 \mu \mathrm{M}$ MTX group. Similarly, the vitamin $\mathrm{C}$ and $0.01 \mu \mathrm{M}$ MTX combination treatment group had lower $\mathrm{H}_{2} \mathrm{O}_{2}$ levels than the $0.01 \mu \mathrm{M}$ MTX group. These data indicate that vitamin $\mathrm{C}$ reduced the MTX-induced $\mathrm{H}_{2} \mathrm{O}_{2}$ levels. However, to our surprise, vitamin $\mathrm{C}$ did not attenuate cell cytotoxicity in the MTX-treated Hep3B cells. On the contrary, our data showed that vitamin $C$ enhanced the anticancer efficacy in MTX-treated Hep3B cells (Fig. 6). As shown in Fig. 6A and $\mathrm{B}$, combination treatments of $5 \mu \mathrm{M}$ vitamin $\mathrm{C}$ and MTX $(0.01$
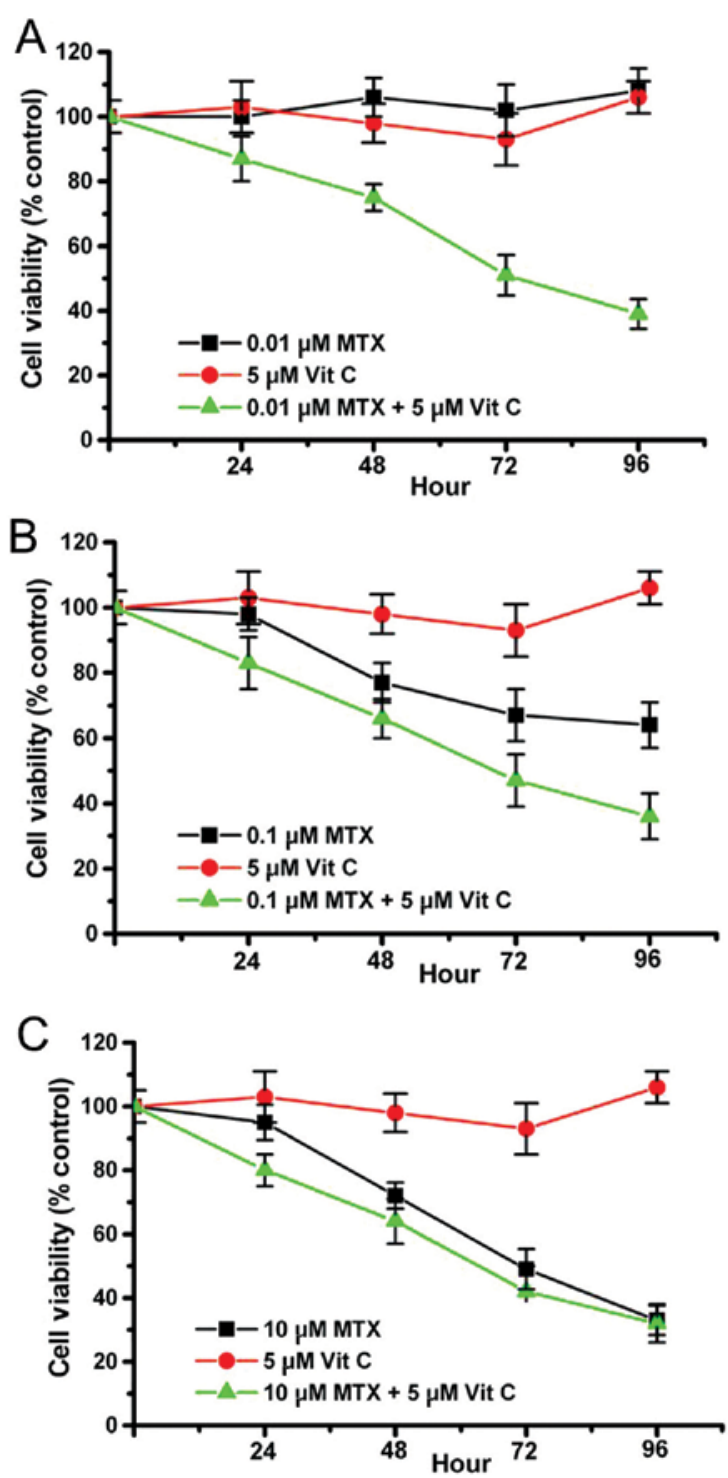

Figure 6. Cell viability. (A) Hep3B cells were treated with $0.01 \mu \mathrm{M}$ MTX, $5 \mu \mathrm{M}$ vitamin $\mathrm{C}$, and a combination of $0.01 \mu \mathrm{M}$ MTX and $5 \mu \mathrm{M}$ vitamin $\mathrm{C}$. (B) Hep3B cells were treated with $0.1 \mu \mathrm{M}$ MTX, $5 \mu \mathrm{M}$ vitamin $\mathrm{C}$ or a combination of $0.1 \mu \mathrm{M}$ MTX and $5 \mu \mathrm{M}$ vitamin C. (C) Hep3B cells were treated with $10 \mu \mathrm{M}$ MTX, $5 \mu \mathrm{M}$ vitamin $\mathrm{C}$ or a combination of $10 \mu \mathrm{M}$ MTX and $5 \mu \mathrm{M}$ vitamin C. Cell viability was measured with MTT assay every $24 \mathrm{~h}$ and is presented as A570 experimental group/A570 control group x $100 \%$. Data were collected from four independent experiments and are presented as means $\pm \mathrm{SD}$ 
or $0.1 \mu \mathrm{M})$ exerted a stronger anticancer effect on Hep3B cells than MTX treatment alone. It is worth noting that $0.01 \mu \mathrm{M}$ MTX alone or $5 \mu \mathrm{M}$ vitamin $\mathrm{C}$ alone did not have a significant cytotoxic effect on Hep3B cells, whereas a combination treatment of $0.01 \mu \mathrm{M}$ MTX and $5 \mu \mathrm{M}$ vitamin $\mathrm{C}$ did induce a cytotoxic effect on Hep3B cells (Fig. 6A). While vitamin C did not enhance the $10 \mu \mathrm{M}$ MTX-induced cytotoxic effect on Hep3B cells (Fig. 6C), the present study was important in indicating that vitamin $\mathrm{C}$ can assist low-dose MTX exert an anticancer effect on Hep3B cells.

\section{Discussion}

Previous reports have revealed that MTX-induced cytotoxicity is related to increased reactive oxygen species (ROS) (35-37). However, no study has shown which ROS are induced following MTX treatment. In the present study, two types of ROS, $\mathrm{O}_{2}$ and $\mathrm{H}_{2} \mathrm{O}_{2}$, were measured. $\mathrm{H}_{2} \mathrm{O}_{2}$ levels in MTX-treated cells rose significantly while $\mathrm{O}_{2}^{-}$levels did not. In addition, it is well known that glutathione can convert toxic $\mathrm{H}_{2} \mathrm{O}_{2}$ into non-toxic $\mathrm{H}_{2} \mathrm{O}$. We suggest that the increase in $\mathrm{H}_{2} \mathrm{O}_{2}$ levels is a possible and important reason why $\mathrm{N}$-acetyl cysteine (NAC), a clinical drug for glutathione synthesis, is used for MTX-induced cell damage $(35,38,39,62)$. On the other hand, high-dose MTX-induced $\mathrm{H}_{2} \mathrm{O}_{2}$ level increases were higher than low-dose MTX-induced $\mathrm{H}_{2} \mathrm{O}_{2}$ level increases (Fig. 4B). Our data also showed that MTX induced cytotoxicity in a dose-dependent manner (Fig. 1). Taken together, we consider increases in the $\mathrm{H}_{2} \mathrm{O}_{2}$ level to be one factor resulting in the inhibition of cell survival following MTX treatment.

MTX has anticancer effects on various hepatoma cell lines, including HepG2, MHCC97, Huh7 and Morris 5123 cells (6,63-67). Alhough the mechanisms involved in the MTX-induced cytotoxic effects on different hepatoma cells remain undetermined, a previous study demonstrated that MTX-induced cytotoxic effects on HepG2 cells are related to the CD95 death receptor pathway (caspase-8/-3 cascade pathway), whereas MTX-induced cytotoxic effects on Huh7 and Hep3B cells are not related to death receptor pathways (65). Similarly, the caspase-8/-3 cascade pathway was also found not to be involved in MTX-treated Hep3B cells in the present study (Fig. 3B). This study further demonstrated that MTX-induced apoptosis in Hep3B cells occurred through the caspase-9/-3 cascade pathway (Fig. 3A and C). These previous studies indicate that MTX induces different caspase pathways in different hepatoma cell lines. HepG2 is a p53 wild-type hepatoma cell line, while Hep3B is a p53-deficient hepatoma cell line $(68,69)$. Thus, we suggest that p53 may be a possible reason for why the caspase-8/-3 pathway was activated in the MTX-treated HepG2 cells, while the caspase-9/-3 pathway was activated in the MTX-treated Hep3B cells.

Previous studies have demonstrated that MTX-induced cell cytotoxicity is associated with increases in reactive oxygen species (ROS) (35-37). The present study also indicated that MTX-induced $\mathrm{H}_{2} \mathrm{O}_{2}$ level increases may be one factor resulting in cell growth inhibition. On the other hand, vitamin $\mathrm{C}$ can reduce oxidative stress against ROS-induced cell damage (43-47). Here, we also demonstrated that vitamin $\mathrm{C}$ did reduce MTX-induced increases in $\mathrm{H}_{2} \mathrm{O}_{2}$ levels. However, vitamin $\mathrm{C}$ did not inhibit MTX-induced cell cytotoxicity in
Hep3B cells. On the contrary, vitamin C assisted low-dose MTX to exhibit a strong cytotoxic effect in Hep3B cells. Similarly, recent studies also indicated that vitamin $\mathrm{C}$ can enhance anticancer agents to exert a strong cytotoxic effect on cancer cells, although the mechanisms remain unknown (48,70-72). Thus, MTX-induced increases in $\mathrm{H}_{2} \mathrm{O}_{2}$ levels may be one of the factors resulting in cytotoxicity noted in MTX-treated Hep3B cells. There are various unclear MTX-induced death signals that remain to be studied. Regardless, a combination treatment of vitamin C and low-dose MTX may be a potential method for hepatoma cancer therapy.

Overall, the present study first demonstrated that MTX induces an increase in $\mathrm{H}_{2} \mathrm{O}_{2}$ levels and activates the caspase9/-3 cascade pathway to cause apoptosis in Hep3B cells. Importantly, a combination treatment of vitamin $\mathrm{C}$ and lowdose MTX exerted a strong anticancer effect in Hep3B cells. This treatment method may be useful for future clinical cancer therapy.

\section{Acknowledgements}

This work was supported by the following grants: NSC1012321-B-039-004; NHRI-EX102-10245BI; TCRD-TPE-102-26 and TCRD-TPE-103-48.

\section{References}

1. Weinblatt ME: Methotrexate in rheumatoid arthritis: a quarter century of development. Trans Am Clin Climatol Assoc 124: 16-25, 2013.

2. Patane $\mathrm{M}$, Ciriaco $\mathrm{M}$, Chimirri S, et al: Interactions among low dose of methotrexate and drugs used in the treatment of rheumatoid arthritis. Adv Pharmacol Sci 2013: 313858, 2013.

3. Cakir T, Ozkan E, Dulundu E, et al: Caffeic acid phenethyl ester (CAPE) prevents methotrexate-induced hepatorenal oxidative injury in rats. J Pharm Pharmacol 63: 1566-1571, 2011.

4. Keystone E, Landewe R, van Vollenhoven R, et al: Long-term safety and efficacy of certolizumab pegol in combination with methotrexate in the treatment of rheumatoid arthritis: 5-year results from the RAPID 1 trial and open-label extension. Ann Rheum Dis: Aug 5, 2013 (Epub ahead of print). doi: 10.1136/ annrheumdis-2013-203695.

5. Cordero MD, Sanchez-Alcazar JA, Bautista-Ferrufino MR, et al: Acute oxidant damage promoted on cancer cells by amitriptyline in comparison with some common chemotherapeutic drugs. Anticancer Drugs 21: 932-944, 2010.

6. Otrocka M, Verschueren H and Malicka-Blaszkiewicz M: The effect of methotrexate on actin and invasiveness of hepatoma Morris 5123 cells in culture. Acta Biochim Pol 48: 1051-1060, 2001.

7. Jolivet J, Cowan KH, Curt GA, Clendeninn NJ and Chabner BA: The pharmacology and clinical use of methotrexate. N Engl J Med 309: 1094-1104, 1983.

8. Takemura Y and Jackman AL: Folate-based thymidylate synthase inhibitors in cancer chemotherapy. Anticancer Drugs 8: 3-16, 1997.

9. Shirao K, Boku N, Yamada Y, et al: Randomized phase III study of 5-fluorouracil continuous infusion vs. sequential methotrexate and 5-fluorouracil therapy in far advanced gastric cancer with peritoneal metastasis (JCOG0106). Jpn J Clin Oncol 43: 972-980, 2013.

10. Chen Y, Zhang W, Gu J, et al: Enhanced antitumor efficacy by methotrexate conjugated Pluronic mixed micelles against KBv multidrug resistant cancer. Int J Pharm 452: 421-433, 2013.

11. Ding L, Hu XM, Wu H, et al: Combined transfection of Bcl-2 siRNA and miR-15a oligonucleotides enhanced methotrexateinduced apoptosis in Raji cells. Cancer Biol Med 10: 16-21, 2013.

12. Florou D, Patsis C, Ardavanis A and Scorilas A: Effect of doxorubicin, oxaliplatin, and methotrexate administration on the transcriptional activity of BCL-2 family gene members in stomach cancer cells. Cancer Biol Ther 14: 587-596, 2013. 
13. Saez-Ayala M, Montenegro MF, Sanchez-Del-Campo L, et al: Directed phenotype switching as an effective antimelanoma strategy. Cancer Cell 24: 105-119, 2013.

14. Yan KH, Lee LM, Hsieh MC, et al: Aspirin antagonizes the cytotoxic effect of methotrexate in lung cancer cells. Oncol Rep 30: 1497-1505, 2013.

15. Ohgidani M, Komizu Y, Goto K and Ueoka R: Residual powders from Shochu distillation remnants induce apoptosis in human hepatoma cells via the caspase-independent pathway. J Biosci Bioeng 114: 104-109, 2012.

16. Yu VW and Ho WS: Tetrandrine inhibits hepatocellular carcinoma cell growth through the caspase pathway and $\mathrm{G} 2 / \mathrm{M}$ phase. Oncol Rep 29: 2205-2210, 2013.

17. Fan CM, Foster BK, Hui SK and Xian CJ: Prevention of bone growth defects, increased bone resorption and marrow adiposity with folinic acid in rats receiving long-term methotrexate. PloS One 7: e46915, 2012.

18. Okamura M, Hashimoto K, Shimada J and Sakagami H: Apoptosis-inducing activity of cisplatin (CDDP) against human hepatoma and oral squamous cell carcinoma cell lines. Anticancer Res 24: 655-661, 2004.

19. Papachristopoulou G, Talieri M and Scorilas A: Significant alterations in the expression pattern of kallikrein-related peptidase genes KLK4, KLK5 and KLK14 after treatment of breast cancer cells with the chemotherapeutic agents epirubicin, docetaxel and methotrexate. Tumour Biol 34: 369-378, 2013.

20. Wehner R, Bitterlich A, Meyer N, et al: Impact of chemotherapeutic agents on the immunostimulatory properties of human 6-sulfo LacNAc ${ }^{+}$(slan) dendritic cells. Int J Cancer 132: 1351-1359, 2013.

21. Zhang D and Loughran TP Jr: Large granular lymphocytic leukemia: molecular pathogenesis, clinical manifestations, and treatment. Hematology Am Soc Hematol Educ Program 2012: 652-659, 2012.

22. Xie XB, Yin JQ, Wen LL, et al: Critical role of heat shock protein 27 in bufalin-induced apoptosis in human osteosarcomas: a proteomic-based research. PloS One 7: e47375, 2012.

23. Yang TM, Qi SN, Zhao N, et al: Induction of apoptosis through caspase-independent or caspase-9-dependent pathway in mouse and human osteosarcoma cells by a new nitroxyl spin-labeled derivative of podophyllotoxin. Apoptosis 18: 727-738, 2013.

24. Green DR and Reed JC: Mitochondria and apoptosis. Science 281: 1309-1312, 1998

25. Thornberry NA and Lazebnik Y: Caspases: enemies within. Science 281: 1312-1316, 1998.

26. Tang CH, Hu CC, Wei CW and Wang JJ: Synergism of Rana catesbeiana ribonuclease and IFN- $\gamma$ triggers distinct death machineries in different human cancer cells. FEBS Lett 579: 265-270, 2005.

27. Yaoxian W, Hui Y, Yunyan Z, Yanqin L, Xin G and Xiaoke W: Emodin induces apoptosis of human cervical cancer hela cells via intrinsic mitochondrial and extrinsic death receptor pathway. Cancer Cell Int 13: 71, 2013.

28. Beaudouin J, Liesche C, Aschenbrenner S, Horner M and Eils R: Caspase- 8 cleaves its substrates from the plasma membrane upon CD95-induced apoptosis. Cell Death Differ 20: 599-610, 2013.

29. Yu YL, Wei CW, Chen YL, Chen MH and Yiang GT: Immunotherapy of breast cancer by single delivery with rAAV2mediated interleukin-15 expression. Int J Oncol 36: 365-370, 2010.

30. Zheng B, Wu L, Ma L, et al: Telekin induces apoptosis associated with the mitochondria-mediated pathway in human hepatocellular carcinoma cells. Biol Pharm Bull 36: 1118-1125, 2013.

31. Yiang GT, Harn HJ, Yu YL, et al: Immunotherapy: rAAV2 expressing interleukin-15 inhibits HeLa cell tumor growth in mice. J Biomed Sci 16: 47, 2009.

32. Chen YX, Lv WG, Chen HZ, Ye F and Xie X: Methotrexate induces apoptosis of human choriocarcinoma cell line JAR via a mitochondrial pathway. Eur J Obstet Gynecol Reprod Biol 143: 107-111, 2009.

33. Shiu LY, Chang LC, Liang CH, Huang YS, Sheu HM and Kuo KW: Solamargine induces apoptosis and sensitizes breast cancer cells to cisplatin. Food Chem Toxicol 45: 2155-2164, 2007.

34. Ehrhardt H, Wachter F, Maurer M, Stahnke K and Jeremias I: Important role of caspase-8 for chemosensitivity of ALL cells. Clin Cancer Res 17: 7605-7613, 2011.

35. Caglar Y, Ozgur H, Matur I, et al: Ultrastructural evaluation of the effect of $\mathrm{N}$-acetylcysteine on methotrexate nephrotoxicity in rats. Histol Histopathol 28: 865-874, 2013.
36. Kolli VK, Abraham P, Isaac B and Selvakumar D: Neutrophil infiltration and oxidative stress may play a critical role in methotrexate-induced renal damage. Chemotherapy 55: 83-90, 2009.

37. Tunali-Akbay T, Sehirli O, Ercan F and Sener G: Resveratrol protects against methotrexate-induced hepatic injury in rats. J Pharm Pharm Sci 13: 303-310, 2010.

38. Ciralik H, Bulbuloglu E, Cetinkaya A, Kurutas EB, Celik M and Polat A: Effects of N-acetylcysteine on methotrexate-induced small intestinal damage in rats. Mt Sinai J Med 73: 1086-1092, 2006.

39. Cetinkaya A, Kurutas EB, Bulbuloglu E and Kantarceken B: The effects of $\mathrm{N}$-acetylcysteine on methotrexate-induced oxidative renal damage in rats. Nephrol Dial Transplant 22: 284-285, 2007.

40. Wu CS, Yen CJ, Chou RH, et al: Cancer-associated carbohydrate antigens as potential biomarkers for hepatocellular carcinoma. PloS One 7: e39466, 2012.

41. Pyrhonen S, Kuitunen T, Nyandoto P and Kouri M: Randomised comparison of fluorouracil, epidoxorubicin and methotrexate (FEMTX) plus supportive care with supportive care alone in patients with non-resectable gastric cancer. Br J Cancer 71: 587-591, 1995.

42. Lu Y, Sun J, Petrova K, et al: Metabolomics evaluation of the effects of green tea extract on acetaminophen-induced hepatotoxicity in mice. Food Chem Toxicol 62: 707-721, 2013.

43. Mukhopadhyay PK, Dey A, Mukherjee S and Pradhan NK: The effect of coadministration of $\alpha$-tocopherol and ascorbic acid on arsenic trioxide-induced testicular toxicity in adult rats. J Basic Clin Physiol Pharmacol 24: 245-253, 2013.

44. Kim H, Bae S, Kim Y, et al: Vitamin C prevents stress-induced damage on the heart caused by the death of cardiomyocytes, through down-regulation of the excessive production of catecholamine, TNF- $\alpha$, and ROS production in Gulo(-/-) mice. Free Radic Biol Med 65C: 573-583, 2013.

45. Eroglu S, Pandir D, Uzun FG and Bas H: Protective role of vitamins $\mathrm{C}$ and $\mathrm{E}$ in diclorvos-induced oxidative stress in human erythrocytes in vitro. Biol Res 46: 33-38, 2013.

46. Murata W, Tanaka T, Kubo I and Fujita K: Protective effects of alpha-tocopherol and ascorbic acid against cardol-induced cell death and reactive oxygen species generation in Staphylococcus aureus. Planta Med 79: 768-774, 2013.

47. Hattiwale SH, Saha S, Yendigeri SM, Jargar JG, Dhundasi SA and Das KK: Protective effect of L-ascorbic acid on nickel induced pulmonary nitrosative stress in male albino rats. Biometals 26 : 329-336, 2013.

48. Alexander B, Fishman AI, Eshghi M, Choudhury M and Konno S: Induction of cell death in renal cell carcinoma with combination of D-fraction and vitamin C. Integr Cancer Ther 12: 442-448, 2013.

49. Nagappan A,Park KI, Park HS, et al: Vitamin C induces apoptosis in AGS cells by down-regulation of $14-3-3 \sigma$ via a mitochondrial dependent pathway. Food Chem 135: 1920-1928, 2012.

50. Vetvicka V and Vetvickova J: Combination of glucan, resveratrol and vitamin $\mathrm{C}$ demonstrates strong anti-tumor potential. Anticancer Res 32: 81-87, 2012.

51. Lee WJ: The prospects of vitamin $\mathrm{C}$ in cancer therapy. Immune Netw 9: 147-152, 2009.

52. Li W, Wu JX and Tu YY: Synergistic effects of tea polyphenols and ascorbic acid on human lung adenocarcinoma SPC-A-1 cells. J Zhejiang Univ Sci B 11: 458-464, 2010.

53. Wei CW, Lin CC, Yu YL, et al: $n$-Butylidenephthalide induced apoptosis in the A549 human lung adenocarcinoma cell line by coupled down-regulation of AP- $2 \alpha$ and telomerase activity. Acta Pharmacol Sin 30: 1297-1306, 2009.

54. Yu YL, Su KJ, Chen CJ, et al: Synergistic anti-tumor activity of isochaihulactone and paclitaxel on human lung cancer cells. J Cell Physiol 227: 213-222, 2012.

55. Yiang GT, Chen YH, Chou PL, Chang WJ, Wei CW and Yu YL: The NS3 protease and helicase domains of Japanese encephalitis virus trigger cell death via caspase dependent and independent pathways. Mol Med Rep 7: 826-830, 2013.

56. Yiang GT, Yu YL, Hu SC, Chen MH, Wang JJ and Wei CW: PKC and MEK pathways inhibit caspase-9/-3-mediated cytotoxicity in differentiated cells. FEBS Lett 582: 881-885, 2008.

57. Chen KH, Li PC, Lin WH, Chien CT and Low BH: Depression by a green tea extract of alcohol-induced oxidative stress and lipogenesis in rat liver. Biosci Biotechnol Biochem 75: 1668-1676, 2011. 
58. Lin BR, Yu CJ, Chen WC, et al: Green tea extract supplement reduces D-galactosamine-induced acute liver injury by inhibition of apoptotic and proinflammatory signaling. J Biomed Sci 16: 35,2009

59. Islam MS, Haq SA, Islam MN, et al: Comparative efficacy of subcutaneous versus oral methotrexate in active rheumatoid arthritis. Mymensingh Med J 22: 483-488, 2013.

60. Yiang GT, Yu YL, Chou PL, et al: The cytotoxic protein can induce autophagocytosis in addition to apoptosis in MCF-7 human breast cancer cells. In Vivo 26: 403-409, 2012.

61. Wei CW, Hu CC, Tang CH, Lee MC and Wang JJ: Induction of differentiation rescues HL-60 cells from Rana catesbeiana ribonuclease-induced cell death. FEBS Lett 531: 421-426, 2002.

62. Cetinkaya A, Bulbuloglu E, Kurutas EB and Kantarceken B: $\mathrm{N}$-acetylcysteine ameliorates methotrexate-induced oxidative liver damage in rats. Med Sci Monit 12: BR274-BR278, 2006

63. Chen J, Xiao XQ, Deng CM, Su XS and Li GY: Downregulation of XIAP expression by small interfering RNA inhibits cellular viability and increases chemosensitivity to methotrexate in human hepatoma cell line HepG2. J Chemother 18: 525-531, 2006.

64. Miller KD, Loehrer PJ, Gonin R, et al: A phase II study of weekly oral methotrexate and zidovudine (AZT) in advanced adenocarcinoma of the pancreas and hepatocellular carcinoma. Invest New Drugs 14: 207-212, 1996.

65. Muller M, Strand S, Hug H, et al: Drug-induced apoptosis in hepatoma cells is mediated by the CD95 (APO-1/Fas) receptor/ ligand system and involves activation of wild-type p53. J Clin Invest 99: 403-413, 1997.
66. Wang Y, Chen H, Liu Y, et al: pH-sensitive pullulan-based nanoparticle carrier of methotrexate and combretastatin A4 for the combination therapy against hepatocellular carcinoma. Biomaterials 34: 7181-7190, 2013.

67. Zhao R, Hanscom M and Goldman ID: The relationship between folate transport activity at low $\mathrm{pH}$ and reduced folate carrier function in human Huh7 hepatoma cells. Biochim Biophys Acta 1715: 57-64, 2005

68. Aden DP, Fogel A, Plotkin S, Damjanov I and Knowles BB: Controlled synthesis of HBsAg in a differentiated human liver carcinoma-derived cell line. Nature 282: 615-616, 1979.

69. Ponchel F, Puisieux A, Tabone E, et al: Hepatocarcinoma-specific mutant p53-249ser induces mitotic activity but has no effect on transforming growth factor $\beta$ 1-mediated apoptosis. Cancer Res 54: 2064-2068, 1994.

70. Held LA, Rizzieri D, Long GD, et al: A Phase I study of arsenic trioxide (Trisenox), ascorbic acid, and bortezomib (Velcade) combination therapy in patients with relapsed/refractory multiple myeloma. Cancer Invest 31: 172-176, 2013.

71. Volta V, Ranzato E, Martinotti S, et al: Preclinical demonstration of synergistic active nutrients/drug (AND) combination as a potential treatment for malignant pleural mesothelioma. PloS One 8: e58051, 2013.

72. Vuyyuri SB, Rinkinen J, Worden E, Shim H, Lee S and Davis KR: Ascorbic acid and a cytostatic inhibitor of glycolysis synergistically induce apoptosis in non-small cell lung cancer cells. PloS One 8: e67081,2013. 